Bull. Chem. Soc. Ethiop. 2012, 26(1), 19-26.

Printed in Ethiopia

ISSN 1011-3924

DOI: http://dx.doi.org/10.4314/bcse.v26i1.3

(c) 2012 Chemical Society of Ethiopia

\title{
SOLID PHASE EXTRACTION OF TRACE AMOUNTS OF PALLADIUM IONS USING MULTIWALLED CARBON NANOTUBE MODIFIED BY N,N'-BIS (2-HYDROXY- BENZYLIDENE)-2,2'(AMINOPHENYLTHIO) ETHANE PRIOR TO DETERMINATION BY FLAME ATOMIC ABSORPTION SPECTROMETRY
}

\author{
T. Shamspur ${ }^{1,2^{*}}$ \\ ${ }^{1}$ Chemistry Department, Shahid Bahonar University, Kerman, Iran \\ ${ }^{2}$ Nanochemistry groups, Shahid Bahonar University, Kerman, Iran
}

(Received December 14, 2010; revised May 16, 2011)

\begin{abstract}
Multiwalled carbon nanotubes modified with N,N'-bis(2-hydroxybenzylidene)2,2'(aminophenylthio) ethane have been developed for the selective separation and/or preconcentration of trace amounts of $\mathrm{Pd}(\mathrm{II})$ in aqueous medium. Parameters including $\mathrm{pH}$ of aqueous solution, flow rates, the amount of ligand and the type of stripping solvents were optimized. It was found that the sorption is quantitative in the $\mathrm{pH}$ range (1.5-4), whereas quantitative desorption occurs instantaneously with $3.0 \mathrm{~mL}$ of $0.3 \mathrm{M} \mathrm{Na}_{2} \mathrm{SO}_{3}$. Linearity was maintained between 0.01 to $22 \mu \mathrm{g} \mathrm{mL}^{-1}$ for $\mathrm{Pd}$ in the final solution. The breakthrough volume was greater than $1800 \mathrm{~mL}$ with an enrichment factor of more than 600 and $6.0 \mu \mathrm{g} \mathrm{L} \mathrm{L}^{-1}$ detection limit $(3 \mathrm{~s}, \mathrm{n}=10)$. The effects of various ions interferences on the percent recovery of palladium ion were studied. The method was successfully applied to the determination of palladium ion in environmental samples.
\end{abstract}

KEY WORDS: Multiwalled carbon nanotubes, Preconcentration, Palladium(II) determination

\section{INTRODUCTION}

Palladium is a metal of economic importance due to its extensive use in metallurgy, in various chemical syntheses, production of dental and medicinal devices and in jewellery manufacture [1]. This metal may enter the environment and interact with complexing materials, such as humic substances [2]. Palladium has no biological role and all palladium compounds should be regarded as highly toxic and carcinogenic. However, palladium chloride was formerly prescribed as a treatment for tuberculosis without too many bad side effects. There is currently much discussion about its bioavailability and toxicology [3]. Thus, due to its increasing use, on the one hand, and the toxicity of Pd(II) compounds to mammals, fish and higher plants, on the other hand, the separation and determination of palladium is of special interest in environmental analysis. Low concentration of Pd in industrial $\left(\mu \mathrm{g} \mathrm{g}^{-1}\right.$ level) and environmental samples ( $\mathrm{ng} \mathrm{g}^{-1}$ level) together with the complexity of the matrix cause much interference during the determination of palladium. Therefore, the application of highly sensitive techniques, such as flame atomic absorption spectrometry (FAAS) [4, 5], graphite furnace atomic absorption spectrometry (GFAAS) [6,7], inductively coupled plasma-atomic emission spectrometry ICPAES $[8,9]$, inductively coupled plasma mass spectrometry ICP-MS $[10,11]$, coupled with a separation and enrichment procedure is necessary [12-14].

Typically, solid-phase extraction (SPE) replaces liquid-liquid extraction as a sample preparation tool and provides a method that is simple and safe to use. The benefits of SPE include high recoveries of analytes, purified extracts, high preconcentration factors, ease of automation, and reduction in the consumption of organic solvents $[15,16]$. The methods for producing solid phase material for SPE include binding the metal ion with chelating agents and adsorption on a solid phase such as octadecylsilane [17, 18], and using chemically bonded silica gel $[19,20]$, activated carbon [21, 22], ion-exchange resins [23, 24], chelating resins [25, 26], zeolites [27-29] and various polymers [30].

*Corresponding author. E-mail: shamspur@gmail.com 
Recently, carbon nanotubes (CNTs) [31, 32] have been used for the extraction and analysis of many different organic and environmental matrices. Moreover, these sorbents modified by suitable ligands, are successfully used for the separation and sensitive determination of metal ions [32-36]. In general, Schiff ligands are among the oldest ligands in coordination chemistry [37]. The Schiff bases derived from salicylaldehyde (salen) as polydentate ligands are known to form very stable complexes with transition metal ions [38, 39].

In the present investigation, the analytical potential of multiwalled carbon nanotubes (MWCNTs) modified with N,N'-bis(2-hydroxybenzylidene)-2,2'(aminophenylthio) ethane (NBHAE) (Figure 1) was examined for preconcentration of $\mathrm{Pd}(\mathrm{II})$ in aqueous samples prior to its flame atomic absorption spectrometric determination. The analytical conditions for the preconcentration (quantitative retentions) of analyte were investigated.

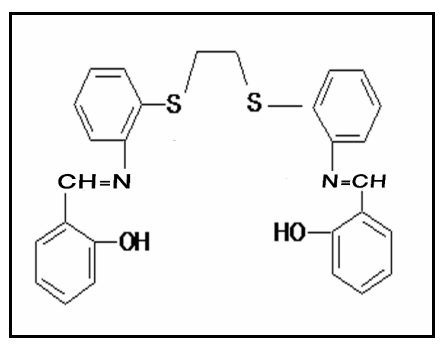

Figure 1. Structure of N,N`-bis(2-hydroxybenzylidene)-2,2`(aminophenylthio) ethane (NBHAE).

\section{EXPERIMENTAL}

\section{Apparatus}

The palladium measurement was performed with a Varian Spectr AA220 atomic absorption spectrometer (Australia) equipped with a computer processor. A palladium hollow cathode lamp, operated at $5 \mathrm{~mA}$, was utilized as the radiation source. The analytical wavelength $(363.5$ $\mathrm{nm})$ and slit width $(0.1 \mathrm{~nm})$ were used as recommended by manufacturers. The $\mathrm{pH}$ values were measured with a metrohm $827 \mathrm{pH}$ meter (Herisau, Switzerland) supplied with a combined glass electrode. A funnel-tipped glass tube $(80 \times 5 \mathrm{~mm})$ was used as column for preconcentration. All glassware and columns were washed with mixture of concentrated hydrochloric acid and concentrated nitric acid (1:1) before use.

\section{Reagents and materials}

All the reagents used were of the highest purity available and at least of analytical reagent grade. The stock solution of $\mathrm{Pd}(\mathrm{II})\left(100 \mu \mathrm{g} \mathrm{mL}^{-1}\right)$ was prepared by dissolving the proper amount of $\mathrm{Pd}\left(\mathrm{CH}_{3} \mathrm{COO}\right)_{2}$ from Merck (Darmstadt, Germany) in 2 mol $\mathrm{L}^{-1}$ hydrochloric acid solution. Standard solutions of $\mathrm{Pd}(\mathrm{II})$ were prepared daily by appropriate dilution of palladium stock solution. Stock solution of diverse elements was prepared from high purity compounds. Multiwalled carbon nanotubes of $95 \%$ purity and length 1-10 $\mu \mathrm{m}$, number of walls 3-15 were purchased from Plasma Chem. GmbH (Germany). The Schiff base ligand NBHAE was synthesized and purified as reported in the literature [40]. A $0.2 \%(\mathrm{~m} / \mathrm{v})$ solution of NBHAE was prepared by dissolving of $50 \mathrm{mg}$ of NBHAE in $1.0 \mathrm{~mL}$ of DMF and diluting to $25.0 \mathrm{~mL}$ with ethanol. 


\section{Preparation of modified MWCNTs}

Prior to use, MWCNTs materials were oxidized with concentrated $\mathrm{HNO}_{3}$ according to literature with minor modification [32]. In order to create binding sites onto the surface, $3.0 \mathrm{~g}$ of MWCNTs were first soaked in $30 \mathrm{~mL}$ of concentration $\mathrm{HNO}_{3}$ for $12 \mathrm{~h}$ at room temperature while being stirred [41]. Then the solution was filtered through a $0.45 \mu \mathrm{m}$ membrane filter and the MWCNTs were washed with distilled water until the $\mathrm{pH}$ was neutral. $2 \mathrm{~g}$ of MWCNTs was suspended in $20 \mathrm{~mL} 0.2 \%(\mathrm{~m} / \mathrm{v})$ solution of NBHAE and the mixture was refluxed with stirring for $4 \mathrm{~h}$. The solid was filtered, washed with water and dried at $80^{\circ} \mathrm{C}$. The amount of NBHAE deposited on the MWCNTs was estimated by spectrometric measurements from the residual amount of NBHAE in solution.

\section{Column preparation}

An aliquot $40.0 \mathrm{mg}$ of modified MWCNTs was slurred in water, and then poured into a funneltipped glass tube $(80 \times 5 \mathrm{~mm})$ plugged with a small portion of cotton at ends. The column could be used repeatedly after washing with distilled water.

\section{Recommended procedure}

Fifty milliliters of an aqueous solution containing $5.0 \mu \mathrm{g}$ of $\mathrm{Pd}(\mathrm{II})$ was taken and the $\mathrm{pH}$ was adjusted to about 2 . The resulting solution was passed through the column at flow rate of about $1 \mathrm{~mL} \mathrm{~min}{ }^{-1}$. After passing of solution completely, the column was rinsed with $5 \mathrm{~mL}$ of water and the adsorbed ions were eluted with $3.0 \mathrm{~mL} 0.3 \mathrm{M} \mathrm{Na}_{2} \mathrm{SO}_{3}$ with a flow rate of $1 \mathrm{~mL} \mathrm{~min}^{-1}$. The $\mathrm{Pd}(\mathrm{II})$ in the eluent were determined by FAAS.

\section{RESULTS AND DISCUSSION}

Some preliminary experiments were carried out in order to investigate the quantitative retention of Pd(II) ions by MWCNTs in the absence and presence of NBHAE. Experimental results showed that MWCNTs have a tendency for the retention of metal ions adsorption $(<40 \%$ for $\mathrm{Pd}^{2+}$ ) but were not selective. Modified multiwalled carbon nanotube with NBHAE has a greater capacity of adsorption and selectivity of ions. In order to achieve the best performance, the separation/preconcentration procedure was optimized for various analytical parameters, such as, the nature and concentration of eluent, $\mathrm{pH}$ of the sample solution, volume and type of the eluent solution, the flow rate of eluent and sample solutions and volume of the sample solution. Various ions interferences effects were also investigated.

\section{Choice of eluent}

One of the important factors that affect the preconcentration procedure is the type, volume and concentration of the eluent used for the removal of metal ions from the sorbent [42]. In order to choose the most effective eluent for the quantitative stripping of the retained $\mathrm{Pd}(\mathrm{II})$ ions by the modified column MWCNTs with NBHAE, after the extraction from $50 \mathrm{~mL}$ water $(\mathrm{pH} 2)$, the $\operatorname{Pd}(\mathrm{II})$ were stripped with $3 \mathrm{~mL}$ of various stripping agents. The results are summarized in Table 1. Results showed that the elution of the retained $\mathrm{Pd}(\mathrm{II})$ was quantitative with $\mathrm{Na}_{2} \mathrm{SO}_{3}$. The effect of varying concentration of $\mathrm{Na}_{2} \mathrm{SO}_{3}$ on the recovery of $\mathrm{Pd}$ (II) was also studied and the results are included in Table 1. As can be seen, $3 \mathrm{~mL}$ of $0.3 \mathrm{M} \mathrm{Na}_{2} \mathrm{SO}_{3}$ solution can accomplish the quantitative elution of $\mathrm{Pd}(\mathrm{II})$ from the modified column. 
Table 1. Percent recovery of Pd(II) from the modified column as a function of stripping solutions ${ }^{\mathrm{a}}$.

\begin{tabular}{|l|c|}
\hline Stripping agent & Recovery $(\%)^{\mathrm{b}}$ \\
\hline $\mathrm{HCl}(0.1 \mathrm{M})$ & $92.0 \pm 0.5$ \\
\hline Thiourea & $89.1 \pm 0.6$ \\
\hline $\mathrm{Na}_{2} \mathrm{~S}_{2} \mathrm{O}_{3}$ & $86.0 \pm 0.5$ \\
\hline $\mathrm{KSCN}$ & $64.3 \pm 1.0$ \\
\hline $\mathrm{Na}_{2} \mathrm{SO}_{3}(0.1 \mathrm{M})$ & $98.0 \pm 0.7$ \\
$\mathrm{Na}_{2} \mathrm{SO}_{3}(0.3 \mathrm{M})$ & $99.6 \pm 0.4$ \\
$\mathrm{Na}_{2} \mathrm{SO}_{3}(0 . .5 \mathrm{M})$ & $99.5 \pm 0.5$ \\
\hline
\end{tabular}

${ }^{\mathrm{a}}$ Initial samples contained $5.0 \mu \mathrm{g} \operatorname{Pd}(\mathrm{II})$ in $50 \mathrm{~mL}$ water. ${ }^{\mathrm{b}}$ Average of four determinations \pm standard deviation.

Effect of the sample $\mathrm{pH}$

One of the most important parameters affecting the preconcentration procedure is the $\mathrm{pH}$ of the solution, because the formation of soluble metal complexes and their stabilities in aqueous solutions are strongly related to the $\mathrm{pH}$ of the medium $[43,44]$. The influence of $\mathrm{pH}$ on the recovery of $\mathrm{Pd}(\mathrm{II})$ was examined in the $\mathrm{pH}$ range of 1-10 (Figure 2). It was found that the sorption is quantitative in the $\mathrm{pH}$ range (1.5-4.0). Therefore the $\mathrm{pH}$ was adjusted to about 2 for subsequent experiments.

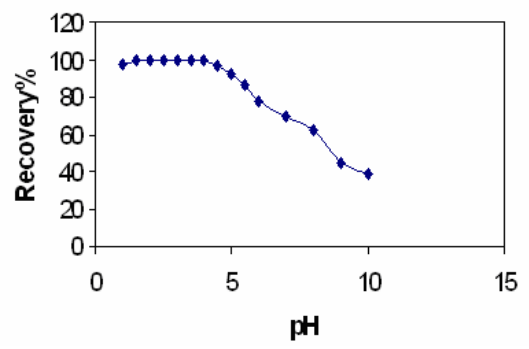

Figure 2. Effect of $\mathrm{pH}$ of sample solution on the recovery of $\mathrm{Pd}(\mathrm{II})$.

Effect of flow rates of sample and eluent solution

The retention of an element on an adsorbent also depends on the flow rate of the sample solution [42]. Thus, the effect of flow rates of the sample and elution solutions on the retention and recovery of ions was investigated under optimum conditions. It was found that retention and recovery of the ions was independent of flow rate in a range of $0.5-1.5 \mathrm{~mL} \mathrm{~min}^{-1}$. Therefore a flow rate of $1 \mathrm{~mL} \mathrm{~min}^{-1}$ was applied for sample and elution solutions in all subsequent experiments.

\section{Breakthrough volume}

The measurement of breakthrough volume is important in solid-phase extraction because breakthrough volume represents the sample volume that can be preconcentrated without loss of analyte during elution of the sample [42]. The breakthrough volume is strongly dependent on the nature of both the sorbent and the trace element, as well as on the mass of sorbent considered and the analyte concentration in the sample [45]. In addition, it depends on the sorbent containers, as discs usually offer higher breakthrough volumes than cartridges. The 
breakthrough volume of sample solution was tested by dissolving $5.0 \mu \mathrm{g} \operatorname{Pd}$ (II) in 50, 100, 500, $1000,1500,1800$ and $2000 \mathrm{~mL}$ water and the recommended procedure was followed under optimal experimental conditions. In all cases to $1800 \mathrm{~mL}$ the extraction by the column was found to be quantitative. Thus, the breakthrough volume for the method should be greater than $1800 \mathrm{~mL}$. Consequently, by considering the final elution volume of $3.0 \mathrm{~mL}$ and the breakthrough volume of $1800 \mathrm{~mL}$, an enrichment factor of 600 was easily achievable.

\section{Adsorption capacity}

The adsorption capacity is the maximum metal quantity taken up by $1 \mathrm{~g}$ of solid phase and given by $\mathrm{mg}$ metal $\mathrm{g}^{-1}$ modified solid phase [46]. The adsorption capacities of modified column were determined by batch and column methods.

\section{Batch method}

Fifty milliliters of solution containing $4.0 \mathrm{mg}$ of palladium at $\mathrm{pH} 2$ was added to $40.0 \mathrm{mg}$ sorbent. After shaking for $30 \mathrm{~min}$, the mixture was filtered. A $10.0 \mathrm{~mL}$ aliquot of the supernatant solution was diluted to $100.0 \mathrm{~mL}$ and determined by FAAS. The capacity of sorbent for $\mathrm{Pd}(\mathrm{II})$ was found $86 \mathrm{mg} \mathrm{g}^{-1}$.

\section{Column method}

In addition the sorption capacity of the column was determined by passing $40.0 \mathrm{~mL}$ of $100.0 \mu \mathrm{g}$ $\mathrm{mL}^{-1}$ of $\mathrm{Pd}(\mathrm{II})$ at $\mathrm{pH} 2$ through the column, followed by the determination of the retained ions using atomic absorption spectrometry. The maximum capacity of the sorbent for $\mathrm{Pd}(\mathrm{II})$ was found $98 \mathrm{mg} \mathrm{g}^{-1}$.

\section{Analytical performance}

Calibration curve was constructed for the determination of Pd(II) according to the general procedure under the optimized conditions. Linearity was maintained between $0.01-22.0 \mu \mathrm{g} \mathrm{mL}^{-1}$ in the final solution with a correlation factor of $0.9999(\mathrm{~A}=0.0446 \mathrm{C}+0.0308)$. The limits of detection (LOD) based on three times the standard deviation of the blank ( $3 S_{\mathrm{b}}$ ) [47] under optimal experimental conditions was $6.0 \mu \mathrm{g} \mathrm{L}^{-1}(\mathrm{n}=10)$. The reproducibility of the proposed method for the extraction and determination of $5.0 \mathrm{mg}$ of $\mathrm{Pd}(\mathrm{II})$ from $50 \mathrm{~mL}$ of water was also studied. The obtained RSD in 10 replicate measurements was $2.43 \%$.

\section{Matrix effects}

Matrix effects are important problem in the determination of metals in real samples [48, 49]. In order to assess the possible analytical applications of the recommended procedure, the interference due to several cations and anions was examined under optimized conditions. For these studies an aliquot of aqueous solution $(50 \mathrm{~mL})$ containing $5.0 \mu \mathrm{g}$ of $\mathrm{Pd}$ (II) was taken with different amounts of foreign ions and the procedure was implemented. The tolerance limit was defined as the highest amount of foreign ions that produced an error no greater than $\pm 3 \%$ in the determination of investigated palladium ions. The results are summarized in Table 2 . The results show that the proposed method is selective and can be used for determination of $\mathrm{Pd}(\mathrm{II})$ in various samples without interference. 
Table 2. Effect of interfering ions ${ }^{\mathrm{a}}$.

\begin{tabular}{|l|c|c|c|}
\hline Coexisting ions & $\begin{array}{c}\text { Ion concentration/Pd } \\
\text { concentration }\end{array}$ & $\begin{array}{c}\text { Coexisting } \\
\text { ions }\end{array}$ & $\begin{array}{c}\text { Ion concentration/Pd } \\
\text { concentration }\end{array}$ \\
\hline $\mathrm{Mg}^{2+}, \mathrm{Ca}^{2+}$ & 4000 & $\mathrm{ClO}_{4}{ }^{-}$ & 2150 \\
\hline $\mathrm{Na}^{+}, \mathrm{NH}_{4}{ }^{-}, \mathrm{K}^{+}$ & $5000^{\mathrm{b}}$ & $\mathrm{Cd}(\mathrm{II})$ & 1100 \\
\hline $\mathrm{CH}_{3} \mathrm{COO}^{-}, \mathrm{NO}_{3}{ }^{-}$ & $5000^{\mathrm{b}}$ & $\mathrm{Pb}(\mathrm{II})$ & 890 \\
\hline EDTA & 500 & $\mathrm{Zn}(\mathrm{II})$ & 800 \\
\hline Tartrate & 650 & $\mathrm{Co}(\mathrm{II})$ & 600 \\
\hline Oxalate & 700 & $\mathrm{Rh}(\mathrm{III})$ & 740 \\
\hline $\mathrm{H}_{2} \mathrm{PO}_{4}{ }^{-}$ & 2500 & $\mathrm{Mn}(\mathrm{II})$ & 250 \\
\hline $\mathrm{HPO}_{4}{ }^{-2}$ & 3000 & $\mathrm{Au}(\mathrm{III})$ & 150 \\
\hline $\mathrm{SO}_{4}{ }^{2-}$ & 2550 & $\mathrm{Cu}(\mathrm{II})$ & 770 \\
\hline $\mathrm{CO}_{3}{ }^{2-}$ & 2050 & $\mathrm{Ni}(\mathrm{II})$ & 820 \\
\hline $\mathrm{PO}_{4}{ }^{3-}$ & 2350 & $\mathrm{Fe}(\mathrm{III})$ & 950 \\
\hline
\end{tabular}

${ }^{a}$ Conditions: Initial samples contained $5.0 \mu \mathrm{g} \mathrm{Pd}^{2+}$ and different amounts of various ions in $50 \mathrm{~mL}$ water. ${ }^{\mathrm{b}} \mathrm{Above}$ which was not tested.

\section{Accuracy and applications}

In order to assess the applicability of the method to real samples with different matrices containing varying amount of a variety of diverse ions it was applied to the separation and recovery of $\mathrm{Pd}$ (II) ions from two different synthetic and three water samples. According to the results, the concentration of $\mathrm{Pd}(\mathrm{II})$ in analyzed water samples was below the LOD of the method. The suitability of the proposed method for the analysis of water samples was checked by spiking samples with 5.0 and $10.0 \mu \mathrm{g} \mathrm{mL}^{-1}$ of $\mathrm{Pd}(\mathrm{II})$. Good recoveries (96-102\%) were achieved for all analyzed samples. The data obtained with the proposed method were presented in Table 3. The results indicate that the proposed method can be reliably used for the determination of palladium in various matrices.

Table 3. Determination of Pd(II) in water and synthetic samples.

\begin{tabular}{|l|c|c|c|}
\hline \multicolumn{1}{|c|}{ Sample } & Spiked $\left(\mu \mathrm{g} \mathrm{mL}^{-1}\right)$ & Found $\left(\mu \mathrm{g} \mathrm{mL} \mathrm{m}^{-1}\right)$ & \multicolumn{1}{c}{ Recovery (\%) } \\
\hline \multirow{3}{*}{ Well water (Shahid Bahonar University) } & - & $\mathrm{N}^{\mathrm{b}}$ & - \\
\cline { 2 - 4 } & 10.0 & $9.9 \pm 0.2$ & 99 \\
\cline { 2 - 4 } & 5.0 & $4.8 \pm 0.1$ & 96 \\
\hline \multirow{3}{*}{ Tap water (Kerman drinking water) } & - & $\mathrm{N} . \mathrm{D}$ & - \\
\cline { 2 - 4 } & 10.0 & $9.8 \pm 0.2$ & 98 \\
\cline { 2 - 4 } & 5.0 & $4.9 \pm 0.3$ & 98 \\
\hline Synthetic sample 1 $^{\mathrm{c}}$ & 5.0 & $4.9 \pm 0.1$ & 98 \\
\hline Synthetic sample 2 & & $5.1 \pm 0.3$ & 102 \\
\hline
\end{tabular}

${ }^{a}$ Average of four determinations \pm standard deviation. ${ }^{b}$ Not detected. ${ }^{\mathrm{c}} \mathrm{Zn}^{2+}, \mathrm{Cd}^{2+}, \mathrm{Ni}^{2+}, \mathrm{Pb}^{2+}, \mathrm{Ba}^{2+}, \mathrm{Fe}^{3+}, \mathrm{Hg}^{2+}$, $\mathrm{Co}^{2+}, \mathrm{Cu}^{2+}, 1 \mathrm{mg}$ of each cation. ${ }^{\mathrm{d}} \mathrm{Mg}^{2+}, \mathrm{Ca}^{2+}, \mathrm{Na}^{+}, \mathrm{NH}_{4}^{+}, \mathrm{K}^{+}, \mathrm{Zn}^{2+}, \mathrm{Cd}^{2+}, \mathrm{Ni}^{2+}, \mathrm{Pb}^{2+}, \mathrm{Ba}^{2+}, \mathrm{Fe}^{3+}, \mathrm{Hg}^{2+}, \mathrm{Co}^{2+}$, $\mathrm{Cu}^{2+}, 3 \mathrm{mg}$ of each cation.

\section{Comparison of this method with other methods}

Several methods have been reported in the literature for the preconcentration and determination of palladium. Some characteristics of previously reported methods such as enrichment factor and LOD are summarized in Table 4 for comparison. As can be seen, the proposed SPE method in this work, for the preconcentration of $\mathrm{Pd}(\mathrm{II})$, shows a high enrichment factor to the previously reported methods. In addition, its low cost and simplicity as well as its high selectivity for Pd(II) 
make it as a suitable quantitative determination method. The method was successfully applied to the determination of trace amount of palladium in water samples with excellent recoveries.

Table 4. Comparison of the published preconcentration methods for Pd with the proposed method.

\begin{tabular}{|l|c|c|c|c|c|}
\hline Preconcentration method & $\begin{array}{c}\text { Determination } \\
\text { method }\end{array}$ & $\begin{array}{c}\text { Enrichment } \\
\text { factor }\end{array}$ & $\begin{array}{c}\text { Detection limit } \\
\left(\mu \mathrm{g} \mathrm{L}^{-1}\right)\end{array}$ & $\begin{array}{c}\text { Linear range } \\
\left(\mu \mathrm{g} \mathrm{L}^{-1}\right)\end{array}$ & Reference \\
\hline SPE & FAAS & 100 & 12 & - & {$[35]$} \\
\hline DLLME $^{\mathrm{a}}$ & FAAS & 45.7 & 90 & $100-2000$ & {$[50]$} \\
\hline DLLME & GFAAS & 156 & 0.0024 & $0.1-5$ & {$[51]$} \\
\hline SFODME based on USD & FAAS & 49.9 & 0.60 & $2-400$ & {$[5]$} \\
\hline SPE & FAAS & 600 & 6.0 & $10-22000$ & This work \\
\hline
\end{tabular}

${ }^{\mathrm{a}}$ Dispersive liquid-liquid microextraction. ${ }^{\mathrm{b}}$ Solidified floating organic drop microextraction based on ultrasounddispersion.

\section{CONCLUSIONS}

Palladium can be determined successfully by using the proposed separation/preconcentration method in the presence of high concentrations of matrix ions. The proposed method is simple, precise and accurate. Recovery values obtained are in the range 96-102\% which demonstrates the applicability of the method and indicates that the method is essentially free from interferences for a large number of diverse ions, which are associated with $\mathrm{Pd}$ in its natural occurrence and industrial samples. Due to relative high preconcentration factor, trace metal ion at ppb level can be determined by this proposed method. The use of organic solvents in the proposed method is eliminated. The reproducibility of the method is at the most $2.43 \%$. The method is economical and during the step of desorption the ligand remains in the modified column, which allows using the column more than once.

\section{ACKNOWLEDGEMENTS}

This paper is dedicated to the memory of the founder of Kerman University, Mr. Alireza Afzalipour.

\section{REFERENCES}

1. Zyłkiewicz, B.G.; Kozłowska, M. Anal. Chim. Acta 2005, 539, 61.

2. Hees, T.; Wenclawiak, B.; Lusting, S.; Schramel, P.; Schwarzer, M.; Schuster, M.; Verstraete, D.; Dams, R.; Hemers, E. Environ. Sci. Pollut. Res. 1998, 5, 105.

3. Lee, S.D. Biochemical Aspects of Environmental Pollutants, Ann Arbor Science Publishers: Ann Arbor; 1980.

4. Praveen, R.S.; Daniel, S.; Prasada Rao, T.; Sampath, S.; Sreenivasa Rao, K. Talanta 2006, $70,437$.

5. Mohamadi, M.; Mostafavi, A. Talanta 2010, 81, 301.

6. Kovacheva, P.; Djingova, R. Anal. Chim. Acta 2002, 464, 7.

7. Wu, Y.; Hu, B.; Jiang, Z.; Chen, Sh. J. Anal. At. Spectrom. 2002, 17, 121.

8. Benkhedda, K.; Dimitrova, B.; Infante, H.G.; Ivanova, E.; Adoms, F.C. J. Anal. At. Spectrom. 2003, 18, 1019.

9. Moldovan, M.; G'omez, M.M.; Palacios, M.A. Anal. Chim. Acta 2003, 478, 209.

10. Bencs, L.; Ravindra, K.; Van Grieken, R., Spectrochim. Acta B 2003, 58, 1723.

11. Zyłkiewicz, B.G. Microchim. Acta 2004, 147, 189. 
12. Jarvis, I.; Totland, M.M.; Jarvis, K.E. Analyst 1997, 122, 19.

13. Bencs, L.; Ravindra, K.; Grieken, R.V. Spectrochim. Acta B 2003, 58, 1723.

14. Ek, K.H.; Morrison, G.M.; Rauch, S. Sci. Total Environ. 2004, 21, 334.

15. Garg, B.S.; Bist, J.S.; Sharma, P.K.; Bhojakm, N. Talanta 1996, 43, 2093.

16. Izatt, R.M.; Bradshaw, J.S.; Bruening, R.L. Pure Appl. Chem. 1996, 68, 1237.

17. Shamspur, T.; Mostafavi, A.; Sheikhshoaie, I. J. AOAC Int. 2008, 91, 865.

18. Shamspur, T.; Mashhadizadeh, M.H.; Sheikhshoaie, I. J. Anal. At. Spectrom. 2003, 18, 1407.

19. Tokman, N.; Akman, S.; Ozcan, M. Talanta 2003, 59, 201.

20. Ngeontae, W.; eungmaitrepirom, W.A.; Tuntulani, T. Talanta 2007, 71, 1075.

21. Kimura, M.; Kawanami, K. Talanta 1979, 26, 901.

22. Ferrua, N.; Cerutti, S.; Salonia, J.A.; Olsina, R.A.; Martinez, L.D. J. Hazard. Mater. 2007, $141,693$.

23. Carrero, P.E.; Tyson, J.F. Analyst 1997, 122, 915.

24. Nabi, S.; Alim, A.; Islam, A.; Amjad, M. J. Sep. Sci. 2005, 28, 2463.

25. Madrakian, T.; Afkhami, A.; Esmaeili, A.Talanta 2003, 60, 831.

26. Seyhan, S.; Colak, M.; Merdivan, M.; Demirel, N. Anal. Chim. Acta 2007, 584, 462.

27. Afzali, D.; Mostafavi, A.; Taher, M.A.; Moradian, A. Talanta 2007, 71, 971.

28. Shamspur, T.; Mashhadizadeh, M.H.; Sheikhshoaie, I. J. Anal. At. Spectrom. 2005, 20, 476.

29. Shamspur, T.; Mostafavi, A. J. AOAC Int. 2009, 92, 1203.

30. Sabermahani, F.; Taher, M.A. Anal. Chim. Acta 2006, 565, 152.

31. Zhou, Q.X.; Xiao, J.P.; Wang, W.D.; Liu, G.G.; Shi, Q.Z.; Wang, J.H. Talanta 2006, 68, 1309.

32. Shamspur, T.; Mostafavi, A. J. Hazard. Mater. 2009, 168, 1548.

33. Khorrami, A.R.; Naeimi, H.; Fakhari, A.R. Talanta 2004, 64, 13.

34. Mashhadizadeh, M.H.; Shamspur, T.; Sheikhshoaie I. Asian J. Chem. 2006, 18, 356.

35. Farhadi, K.; Teimouri, G. Talanta 2005, 65, 925.

36. Tuzen, M.; Soylak, M. J. Hazard. Mater. 2007, 147, 219.

37. Razee, S.; Masujima, T. Anal. Chem. Acta 2002, 464, 1.

38. Alizadeh, N.; Ershad, S.; Naeimi, H.; Sharghi, H.; Shamsipur, M. Polish J. Chem. 1999, 73, 915.

39. Shamsipur, M.; Ghiasvand, A.R.; Sharghi, H.; Naeimi, H. Anal. Chim. Acta 2000, 408, 271.

40. Barbosa, A.F.; Segatelli, M.G.; Pereira, A.C.; Santos, A.S.; Kubota, L.T.; Luccas, P.O.; Tarley, C.R.T. Talanta 2007, 71, 1512.

41. Li, Q.L.; Yuan, D.X.; Lin, Q.M. J. Chromatogr. A 2004, 1026, 283.

42. Mester, Z:; Sturgeon, R. Sample Preparation for Trace Element Analysis, Elsevier: Amsterdam; 2003.

43. Tokalı־ glu, S.; Oymakb, T.; Kartal, S. Anal. Chim. Acta 2004, 511, 255.

44. Tuzen, M.; Soylak, M. J. Hazard. Mater. 2006, 129, 266.

45. Hennion, M.C. Trends Anal. Chem. 1991, 10, 317.

46. Ghaedi, M.; Shokrollahi, A.; Kianfar, A.H.; Pourfarokhi, N.; Khanjari, A.; Mirsadeghi, A.S.; Soylak, M. J. Hazard. Mater. 2009, 162, 1408.

47. Miller, J.C.; Miller, J.N. Statistics for Analytical Chemistry, Ellis Harwood: Chichestor; 1984.

48. He, Q.; Chang, X.; Huang, X.; Hu, Z. Microchim. Acta 2008, 160, 147.

49. Bag, H.; Elci, A.; Elci, L. J. Anal. Chem. 2006, 1, 42.

50. Kokya, T.A.; Farhadi, K. J. Hazard. Mater. 2009, 169, 726.

51. Liang, P.; Zhao, E.; Li, F.Talanta 2009, 77, 1854. 